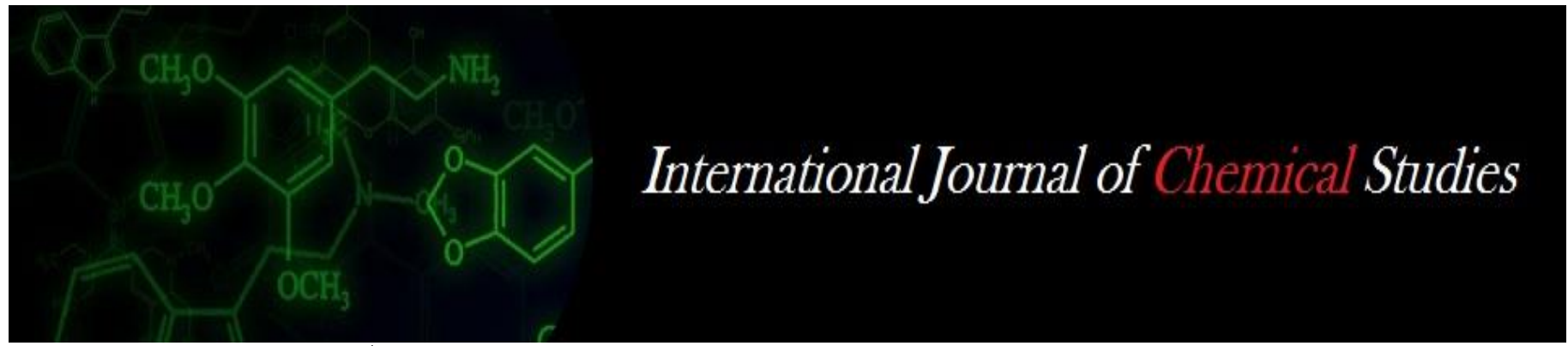

P-ISSN: 2349-8528

E-ISSN: 2321-4902

www.chemijournal.com

IJCS 2020; 8(4): 3919-3925

(C) 2020 IJCS

Received: 10-04-2020

Accepted: 03-06-2020

Divya Shrivastava

M.Sc. (Ag), Department of Agro-

Meteorology, College of

Agriculture, Indira Ghandhi

Krishi Vishwavidyalaya, Raipur,

Chhattisgarh, India

\section{Shri JL Chaudhary}

Senior Scientist, Department of

Agro-meteorology, College of

Agriculture, Indira Ghandhi

Krishi Vishwavidyalaya, Raipur,

Chhattisgarh, India
Corresponding Author: Divya Shrivastava M.Sc. (Ag), Department of AgroMeteorology, College of Agriculture, Indira Ghandhi Krishi Vishwavidyalaya, Raipur, Chhattisgarh, India

\title{
Trends of south-west monsoon onset and withdrawal in different agro-climatic zones of Chhattisgarh
}

\section{Divya Shrivastava and Shri JL Chaudhary}

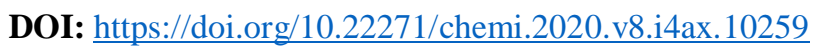

\begin{abstract}
This paper presents the analysis of the onset and withdrawal trends of South-West Monsoon over the last 30 years (1989-2018) in various agro-climatic zone of Chhattisgarh. The trend analysis revealed that both the south-west monsoon's onset and withdrawal have been delayed in recent years. The timing of the Indian Summer Monsoon (ISM)'s dramatic 'onset' and subsequent northward progression are unique features of the annual monsoon cycle, and are closely linked to agricultural activity preparation and water management. Rice cultivation in Chhattisgarh is mainly rain-fed and naturally vulnerable to the variability of south-west monsoons. The purpose of this research was to determine the temporal shift of monsoon onset and withdrawal over a 30-year period in various agro-climatic zones of Chhattisgarh. The variability of monsoon's onset and withdrawal dates was calculated using basic statistical methods such as mean deviation, standard deviation, and linear trend analysis. With standard deviation and CV percent, we calculated the mean onset and withdrawal dates. We found that the mean onset date for monsoon was 14th, 16th and 18th June respectively for BPZ, CPZ and NHZ and found that the mean withdrawal date for monsoon was 11th October (for state) with a standard deviation of 5 days. The trend of monsoon onset dates for all three agro-climatic zones of Chhattisgarh showing a delayed trend but only the NHZ was showing significant delayed trend at $5 \%$ level of significance $\left(\mathrm{R}^{2}=0.149\right)$. The highest value of coefficient of variation of onset dates of monsoon was recorded in Bastar Plateau zone $(37 \%)$ and least in Northern hill zone $(31 \%)$. In case of withdrawal of monsoon results indicates that the state showed significantly delayed monsoon withdrawal trend at $5 \%$ level of significance $\left(R^{2}=0.172\right)$ for the period of 1989-2018
\end{abstract}

Keywords: Monsoon onset, monsoon withdrawal, duration, trends

\section{Introduction}

Indian summer monsoon rainfall (ISMR) contributes approximately $80 \%$ to the total annual precipitation over India (Jain and Kumar, 2012) ${ }^{[7]}$. The southwest monsoon, with its variability in onset and withdrawal dates (Sabeerali et al. 2012) ${ }^{[11]}$, total rainfall (Rupa Kumar et al. 1992) ${ }^{[10]}$, extremes (Ghosh et al. 2012) ${ }^{[6]}$ and intra seasonal oscillations (Singh et al. 2014, Goswami and Ajayamohan, 2001) [13, 4], has significant impacts on the country's agricultural output and hence on the gross domestic product (GDP) of the country (Gadgil and Gadgil, 2006) ${ }^{[3]}$. The beginning of the Indian summer monsoon (ISM) has a significant influence on agriculture, especially since the crop calendar for rain-fed agriculture depends largely on the onset dates (Rosenzweig and Binswanger, 1992) ${ }^{[9]}$. This highlights the need for a reliable prediction of the onset of monsoons, which requires extensive research and analysis on the onset phenomenon and its variability.

Chhattisgarh is a dominant State in agriculture. Chhattisgarh famous for the production of rice. The rice ( 68.8 per cent) has been found to be the state's major crop. Favorable soil and climatic conditions helped the state become a leading paddy producer. The state of Chhattisgarh divided into 3 agro-climatic zones based on the various agro-climatic factors. Chhattisgarh's climate is too tropical. Due to its proximity to the tropical cancer, and its reliance on the monsoon for rains, it is hot and humid. The arrival of south-western monsoon has a major effect on agriculture, largely because the rain-fed crop calendar essentially depends on the beginning dates of the monsoon. 
The practice of agriculture in India begins with the onset of the southwest monsoon. Pre-monsoon rainfall is very critical for field preparation and sowing of kharif crops. The transplantation of rice seedlings will also be delayed if the start of the monsoon is postponed and the rice output eventually decreased. In case of delayed onset of monsoon delays crop sowing has resulted in reduced yields. Similarly, early withdrawal of monsoon impacts production, especially when the kharif crops are at critical grain formation and grain development stages due to severe moisture stress. In particular the northern and southern regions of Chhattisgarh lack adequate irrigation facilities due to their hilly terrain. In addition, the absence of residual soil moisture leaves almost half of the arable soil fallow for any second crop, making things even harder for farmers, declining average rainfall and irregular rainfall patterns have affected Chhattisgarh's rain-fed paddy cultivation. According to a study, of Department of Agrometeorology at the Indira Gandhi Agriculture University in Raipur (Chhattisgarh), annual rainfall has decreased from the normal $1.400-1.600 \mathrm{~mm}$ to $1.200-1.400 \mathrm{~mm}$. "Earlier, rain would last 80-90 days during the monsoon; now it has decreased to 65 days," the study also says there has been a change in the Kharif crop season in the last threesome. This has consequences for the paddy crop, where long-lived varieties no longer have enough time to mature. Water requirement in this rainfed rice system depends solely on the unpredictable southwest monsoon (SM) distribution. Strong downpour at the beginning of south west monsoon, sudden mid-monsoon break (Chand et al. 2012; Mishra, 2012) ${ }^{[1,8]}$, and early withdrawal of monsoon rain raise dry spell frequency at various rice growth stages. As a result, rice production during peak growing seasons frequently suffers from intermittent water stress and even contributes to occasional crop failure. In such circumstances, knowledge on appropriate crop scheduling is important for overcoming shortcomings associated with prolonged droughts during periods of rice-growing. Knowledge of the requirement for crop water (CWR) at different sensitive rice stages is an important practical factor for planning crops (Choudhury et al., 2013) ${ }^{[2]}$. Lack of such information on the variability of monsoon rainfall and its impact on rice productivity is the major bottleneck in the development of sustainable management approaches (including crop planning) to cope with the adverse effect of rainfall variability on rice productivity on the state.

Climate change is gradually starting to impact India's most important cog - agriculture - economic wheel. Rain-fed agricultural systems are going through a tough hit with monsoons being unpredictable and rain scarce. Agriculture and its related sectors provide employment for about 80 percent of Chhattisgarh's rural population, and make up 16 percent of the state's Gross Domestic Product (GDP). For this $80 \%$, more than half, about $46 \%$, are marginal farmers and most depend on rain-fed mono-crop agriculture, rendering them most vulnerable to climate change impacts. Taking into account these variations and the impact of future monsoon variability on rice production, the present study aimed to find out the trend of monsoon onset and withdrawal dates in various agro-climate zones in Chhattisgarh. We also calculated mean monsoon onset and withdrawal dates for all three agro-climatic zones and evaluated early, normal and late monsoon onset and withdrawal categories.
The Chhattisgarh, India's 26th state, was formed from Madhya Pradesh in November 2000. It includes about onethird of Madhya Pradesh's undivided geographical area. The Chhattisgarh extends from 17046 ' $\mathrm{N}$ to $2405^{\prime} \mathrm{N}$ latitude and from $80015^{\prime} \mathrm{E}$ to $84020^{\prime} \mathrm{E}$ longitude southeast of Madhya Pradesh. Its climate is mainly of dry sub-humid type. The total geographical area of the state is around 13.50 million hectares. The research was carried out with the Chhattisgarh agro-climatic zones. The state has three agro-climatic zones, the plains of Chhattisgarh, the Bastar Plateau and the Northern Hills, covering $51.0 \%, 28.0 \%$ and $21.0 \%$ of the geographical area, respectively. The districts represented for agro-climatic zones are Surguja (NHZ), Raipur (CPZ) and Jagdalpur (BPZ). On the basis of available database the mean annual rainfall of Chhattisgarh is $1190 \mathrm{~mm}$ with a coefficient of variation of $26 \%$. Annual rainfall is highest over Bastar plateau zone $(1348 \mathrm{~mm})$ and lowest in Chhattisgarh plains $(1127 \mathrm{~mm})$ while it is intermediary over the Northern hill's zones $(1253 \mathrm{~mm})$. The location of the state is such that it is close to the Bay of Bengal, which is instrumental in bringing monsoon in the Southern side of the country.

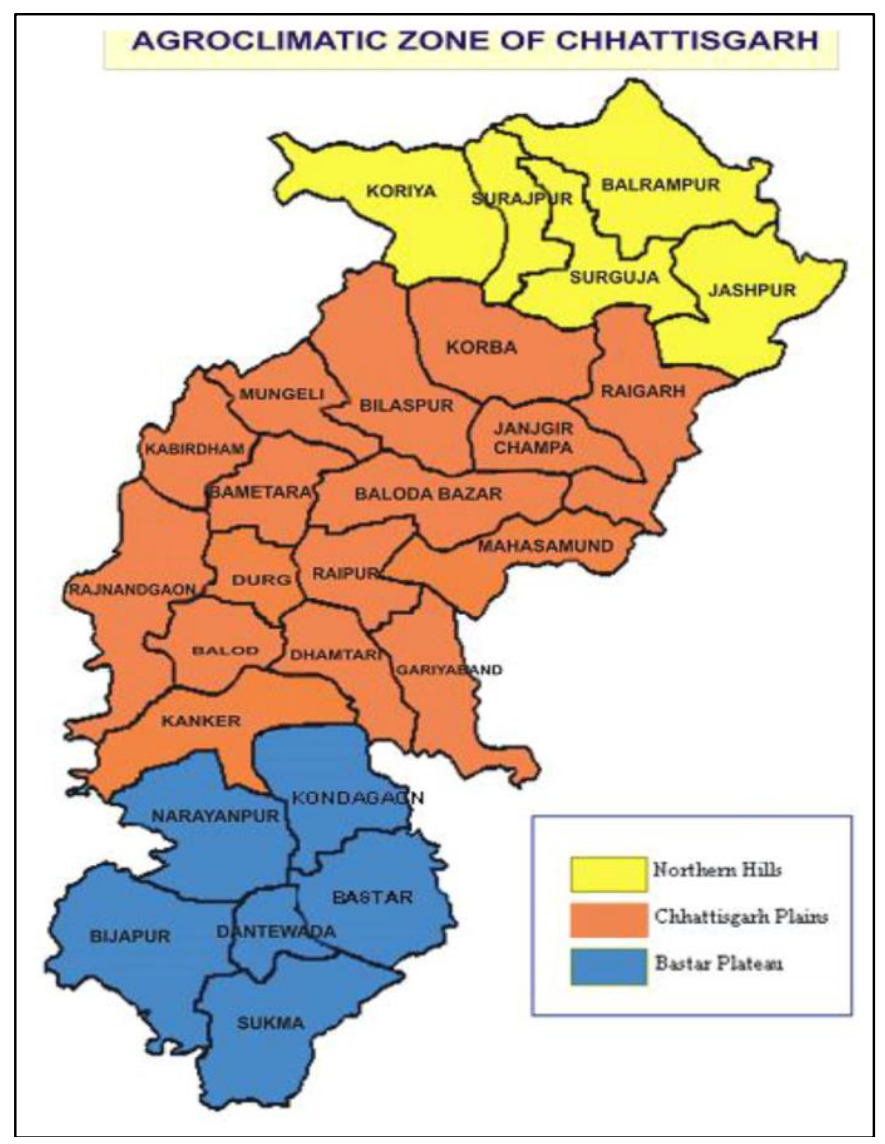

Fig 1: Agro-climatic zones of Chhattisgarh

\section{Materials and Methods}

This section addresses the various materials and methods used during the study period to achieve the objectives. Zone wise monsoon onset and withdrawal data were collected from the Raipur Meteorological Center for the period 1989-2018. The data is used to classify long-term trends of south west monsoon. Here following methods are used to evaluate mean dates, monsoon categories, variability and trend of monsoon onset and withdrawal. 
The mean is the centre of gravity of a distribution; it would be the $\mathrm{x}$-value of the point of frequency curve could be blocked out and manipulated in a solid form. It is given by the formula.

$$
\mathrm{X}=(\Sigma \mathrm{xi}) / \mathrm{n}
$$

Where, $\Sigma$ xi represents the sum of all the observations And ' $n$ ' is number of observations

\section{Standard deviation}

Its calculation is based on the deviations from the arithmetic mean. It is defined as the square root of the mean of the square of deviation of the onset dates from the arithmetic mean of all such onset dates. It is a measure of variability or the scatter or the dispersion about the mean value. It is given by the following formula.

$$
\sigma=\sqrt{\frac{\sum(X-\bar{X})^{2}}{n-1}}
$$

Where,

$x=$ Actual onset date

$\mathrm{n}=$ Number of years

$\bar{x}=$ Mean onset date

\section{Linear Regression}

The linear regression analysis was used to find the trends of monsoon onset and withdrawal in different agro-climatic zones. A linear trend line was added to the series to simplify the trends. A positive value of $\mathrm{R}^{2}$ indicates an increasing trend and vice-versa. Regression analysis is a mathematical measure of the average relationship in terms of original data between two or more variables. In regression analysis there are two kinds of factors. The variable the value of which is affected or is to be predicted is called dependent variable and the variable that affected the value or is used for prediction is called independent variable. In regression analysis independent variable is also known as regression or predictor or explanatory variable while the dependent variable is also known as explained variable. There is a linear regression equation

$$
\mathrm{Y}=\mathrm{a}+\mathrm{bx}
$$

Where,

$\mathrm{Y}=$ Dependent variable

$\mathrm{b}=$ Slope

$\mathrm{a}=$ Intercept

$\mathrm{x}=$ Independent variable like time or rainfall

\section{Variability analysis (Coefficient of variation)}

Simple descriptive statistics along with Co-efficient of Variation were worked to understand the variability nature of onset and withdrawal date of monsoon for all three agro climatic zone of Chhattisgarh. This is a relative dispersion measure as well. Assessment of variability in the onset of monsoon was carried out by Coefficient of variation (CV\%). $\mathrm{CV}$ is defined as the Standard deviation divided by the mean value. It is expressed in percentage, and used to compare the variability in the two or more series. Lesser value of coefficient of variation indicates more consistency. It shows the variability of onset and withdrawal dates in percentage.

$$
\mathrm{CV} \%=\frac{S D}{M E A N} \times 100
$$

\section{Results}

\section{Trends of monsoon onset}

Table 1 shows the date of monsoon onset, date of monsoon withdrawal and the duration of southwest monsoon during the study period (1989-2018). The data indicates a high variation in the dates of onset and withdrawal of south-west monsoon. The duration of the monsoon season shows variations of 108133 days for BPZ, 106-131 days for CPZ and 100 to 130 days for NHZ. The pattern of monsoon onset was analyzed for the Bastar Plateau agro-climatic region of Chhattisgarh, which showed that the onset of monsoon (OEM) varies between 6 June and 26 June. It can be seen very well that the monsoon onset in the $\mathrm{CG}$ state is the first in Bastar Plateau A.C.Z. about 14 June with a coefficient of variation of 37 percent as the SD value is 5.16. It was interpreted from this study that the onset of the monsoon from 9 June to 19 June could be considered the normal onset of the monsoon. The mean date of onset of the monsoon for the Bastar Plateau region is therefore 14 June with a standard deviation of 5 days. Out of 30 years (1989 to 2018) 22 years $(1989,1992,1993,1994$, 1995, 1996, 1997, 1998, 1999, 2002, 2004, 2007, 2008, 2011 , $2012,2014,2015,2016,2017)$ are normal, 5 years $(1990$, $1991,2000,2006,20013,2018)$ are early and 2 years $(2005$, 2009) are late monsoon years. The onset pattern was shown in Figure 4.1. This suggested that the B.P.Z. displayed a delay onset trend for the study period.

The onset of the monsoon in C.P.Z. ranges from $6^{\text {th }}$ June to $26^{\text {th }}$ June. In the Chhattisgarh plains zone, the mean date for the onset of southwest monsoon is June 16 with an SD value of 5.48 (Table 2). It can therefore be said that $11^{\text {th }}$ June to $21^{\text {st }}$ June can be considered a normal monsoon onset. The CV of the onset date fluctuates 34.29 per cent. Out of 30 years 19 years $(1989,1990,1992,1993,1994,1995,1996,1997,1998$, 1999, 2002, 2010, 2011, 2014, 2015, 2016, 2017) are normal, 6 years $(1991,2000,2001,2008,2013,2018)$ are early and 5 years $(2003,2005,2006,2007,2009)$ are late monsoon onset years. The onset trend was shown in Fig 4.2. This suggested that the C.P.Z. displayed a delay onset pattern for the period 1989-2018.

The onset of effective monsoon (OEM) in N.H.Z. varies from 7 June to 29 June. In the northern hill zone, the mean date of the monsoon onset is 18 June with the S.D. Therefore, the onset of the monsoon between $13^{\text {th }}$ June and $23^{\text {rd }}$ June can be considered the usual onset of the monsoon in the northern hill zone of Chhattisgarh. Onset date CV fluctuates by 30.69 percent. Out of 30 years 19 years $(1989,1990,1992,1993$, 1995, 1996, 1997, 1998, 2001, 2003, 2004, 2011 , 2012, 2014, 2015, 2016, 2017), 6 years are regular $(1991,1994,1999$, $2000,2008,2013)$ are early and 5 years $(2005,2006,2007$, $2009,2018)$ are late monsoon years. The onset trend is shown in Figure 4.3. During the study period, the dates of monsoon Onset seem to be delayed from the normal monsoon onset dates to 43, 53 and 50 percent years respectively for BPZ, CPZ, NHZ. The maximum delay is 13 days in 2009. The onset dates display a slightly delayed pattern of $0.09(\mathrm{BPZ})$, $0.14(\mathrm{CPZ})$ and $0.24(\mathrm{NHZ})$ days per year for the entire data collection (1989-2018). 
Table 1: Onset dates, withdrawal dates and period of south west monsoon for represented districts of agro-climatic zones.

\begin{tabular}{|c|c|c|c|c|c|c|c|}
\hline \multicolumn{8}{|c|}{ Dates of Onset And Withdrawal Of Southwest-Monsoon In C.G. } \\
\hline \multicolumn{7}{|c|}{ Onset date (In June) and duration } & \multirow{3}{*}{$\begin{array}{c}\text { Withdrawal dates of monsoon for Chhattisgarh } \\
\text { DATE } \\
\end{array}$} \\
\hline \multirow{2}{*}{ Year } & \multicolumn{2}{|c|}{ Jagdalpur } & \multicolumn{2}{|c|}{ Raipur } & \multicolumn{2}{|c|}{ Ambikapur } & \\
\hline & Date & Duration & Date & Duration & Date & Duration & \\
\hline 1989 & 13 & 114 & 13 & 114 & 15 & 112 & 05 -Oct \\
\hline 1990 & 6 & 132 & 13 & 125 & 15 & 123 & $16-$-Oct \\
\hline 1991 & 7 & 122 & 8 & 121 & 8 & 121 & 07-Oct \\
\hline 1992 & 18 & 119 & 19 & 118 & 20 & 117 & 15-Oct \\
\hline 1993 & 15 & 113 & 16 & 112 & 17 & 111 & 06-Oct \\
\hline 1994 & 11 & 126 & 12 & 125 & 11 & 126 & 15-Oct \\
\hline 1995 & 17 & 109 & 18 & 108 & 18 & 108 & 04-Oct \\
\hline 1996 & 18 & 112 & 18 & 112 & 22 & 108 & 08-Oct \\
\hline 1997 & 18 & 112 & 18 & 112 & 20 & 110 & 08-Oct \\
\hline 1998 & 14 & 115 & 14 & 115 & 15 & 114 & 07-Oct \\
\hline 1999 & 12 & 122 & 14 & 120 & 12 & 122 & 12-Oct \\
\hline 2000 & 6 & 120 & 6 & 120 & 7 & 119 & 04-Oct \\
\hline 2001 & 9 & 126 & 9 & 126 & 13 & 122 & 13-Oct \\
\hline 2002 & 11 & 121 & 20 & 112 & 20 & 112 & 10-Oct \\
\hline 2003 & 17 & 116 & 23 & 110 & 23 & 110 & 11-Oct \\
\hline 2004 & 13 & 120 & 15 & 118 & 15 & 118 & 11-Oct \\
\hline 2005 & 24 & 108 & 24 & 108 & 24 & 108 & $10-$ Oct \\
\hline 2006 & 6 & 129 & 24 & 111 & 24 & 111 & 13-Oct \\
\hline 2007 & 18 & 119 & 24 & 113 & 25 & 112 & 15 -Oct \\
\hline 2008 & 10 & 125 & 10 & 125 & 11 & 124 & 13-Oct \\
\hline 2009 & 26 & 116 & 29 & 113 & 29 & 113 & 20-Oct \\
\hline 2010 & 14 & 109 & 17 & 106 & 18 & 105 & 01-Oct \\
\hline 2011 & 15 & 131 & 17 & 129 & 17 & 129 & $24-O c t$ \\
\hline 2012 & 19 & 118 & 19 & 118 & 21 & 116 & 15-Oct \\
\hline 2013 & 8 & 133 & 10 & 131 & 10 & 131 & 19-Oct \\
\hline 2014 & 19 & 120 & 19 & 120 & 19 & 120 & $17-$-Oct \\
\hline 2015 & 13 & 127 & 15 & 125 & 19 & 121 & 18 -Oct \\
\hline 2016 & 18 & 119 & 19 & 118 & 19 & 118 & 15-Oct \\
\hline 2017 & 14 & 125 & 21 & 118 & 22 & 117 & 17-Oct \\
\hline 2018 & 8 & 119 & 9 & 118 & 27 & 100 & 05-Oct \\
\hline Mean Values & 14 & 120 & 16 & 117 & 18 & 116 & 11-Oct \\
\hline
\end{tabular}

Table 2: Statistical summary of onset and withdrawal of monsoon in different zones.

\begin{tabular}{|c|c|c|c|c|c|}
\hline \multicolumn{7}{|c|}{ Statistical summary of monsoon onset } \\
\hline ZONE & Mean & S.D. & C.V. \% & Regression Equation & $\mathbf{R}^{\mathbf{2}}$ \\
\hline B.P.Z. & 14 & 5.16 & 36.9 & Y=0.091x-1.524 & 0.024 \\
\hline C.P.Z. & 16 & 5.48 & 34.3 & Y=0.140x-1.742 & 0.05 \\
\hline N.H.Z. & 18 & 5.52 & 30.7 & Y=0.242x-3.898 & $0.149 *$ \\
\hline \multicolumn{7}{|c|}{ Statistical summary of monsoon withdrawal } & $\mathrm{R}^{2}$ \\
\hline \multirow{2}{*}{ For state } & Mean & S.D. & C.V.\% & Regression Equation & $0.172 *$ \\
\cline { 2 - 6 } & 11 & 5.4 & 46 & Y $=0.259 x-4.227$ & \\
\hline
\end{tabular}

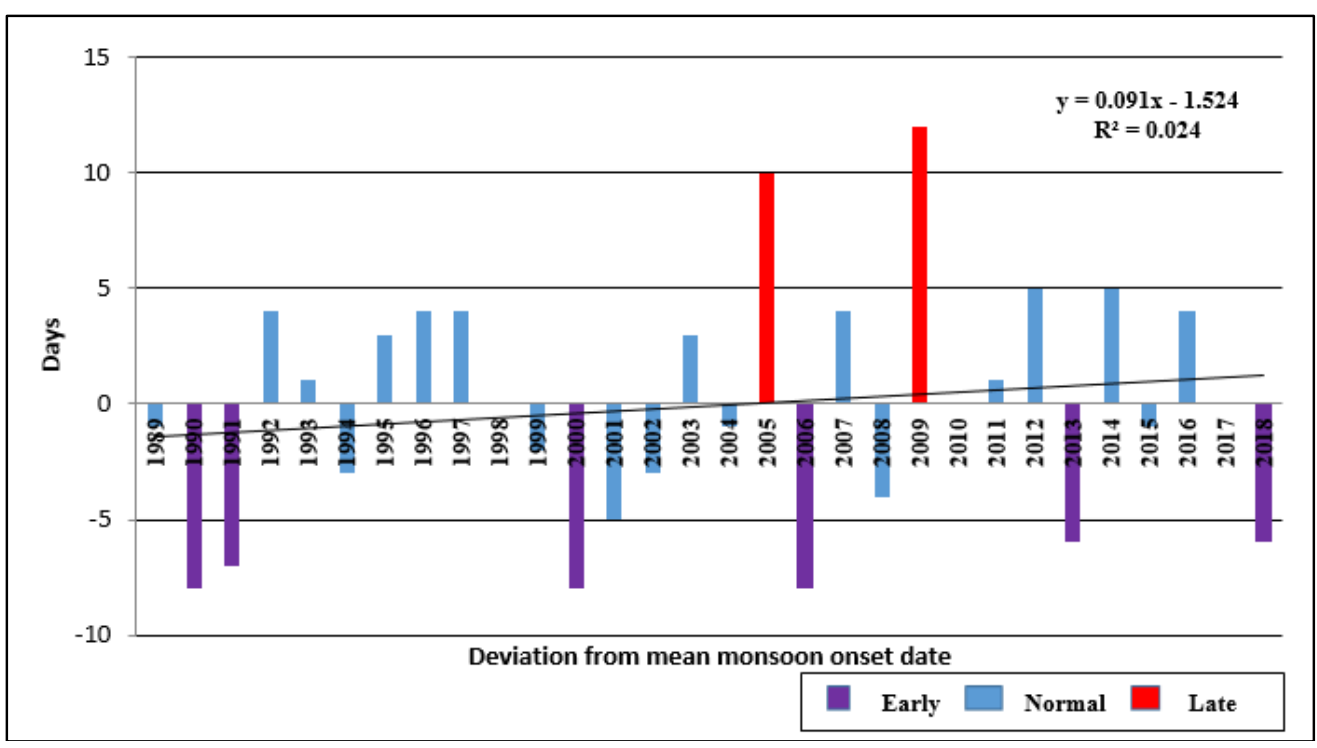

Fig 2: Trend of monsoon onset in BPZ. 


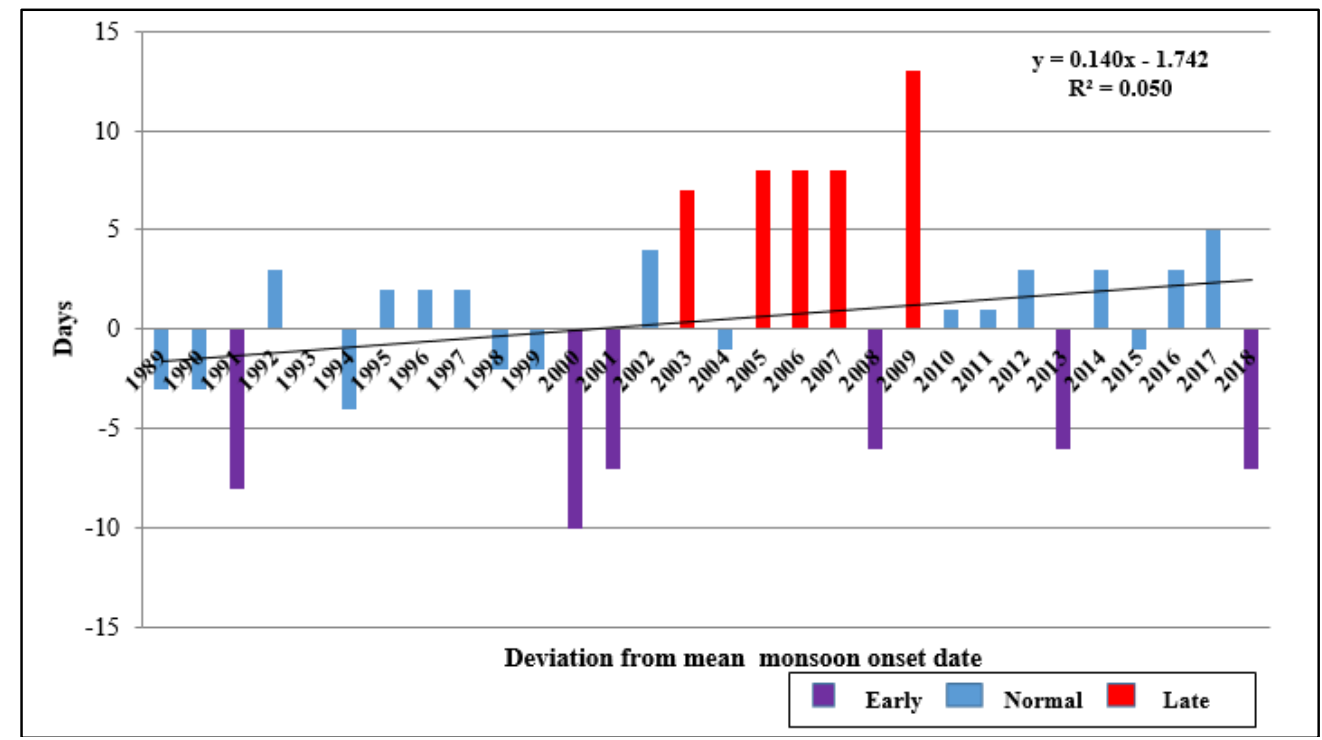

Fig 3: Trend of monsoon onset in CPZ.

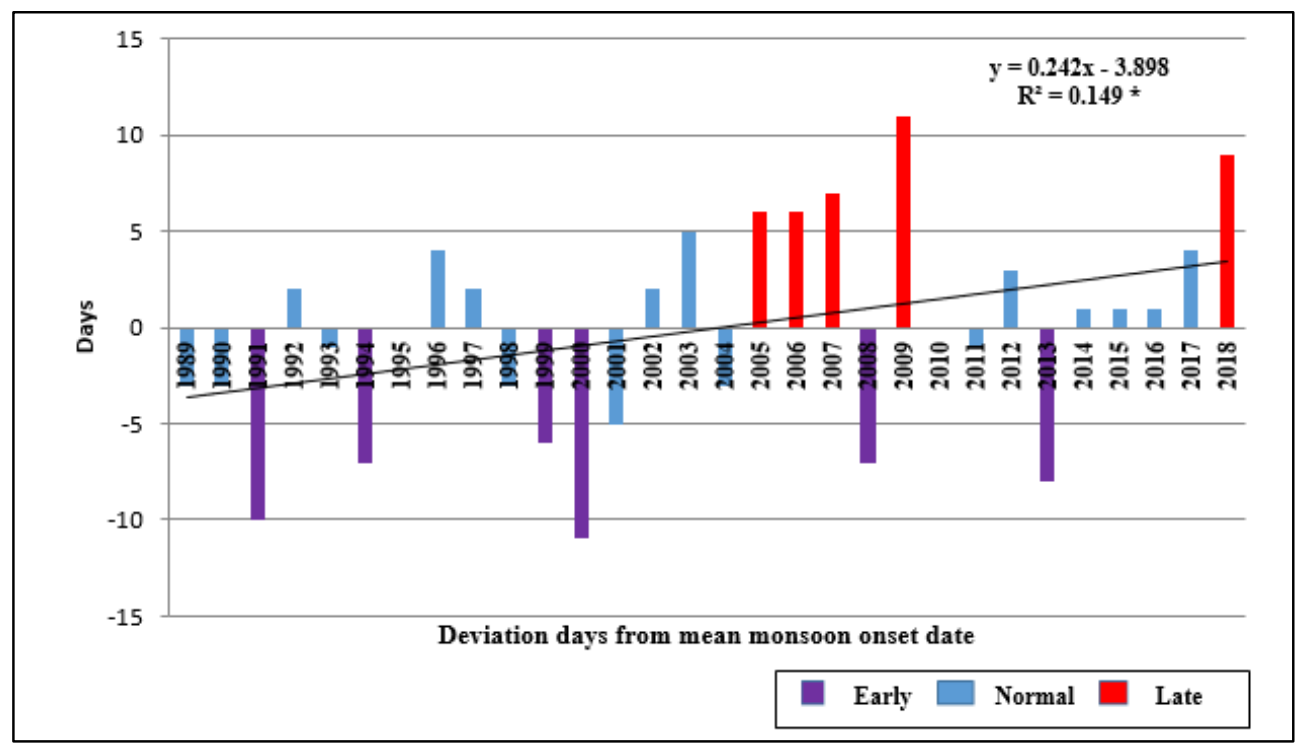

Fig 4: Trend of monsoon onset in NHZ

\section{Trend of monsoon withdrawal}

The withdrawal date of monsoon was observed from 4th to 24th October. The mean date of withdrawal of monsoon for Chhattisgarh state is 11th October with a standard deviation of 5 days. The $\mathrm{CV}$ of onset date fluctuates 46 percent. The dates of withdrawal are also found to be later than the normal date for $50 \%$ of years, the maximum delay being 13 days in 2011. Out of 30 years 20 years $(1990,1991,1992,1994$, 1996, 1997, 1998, 1999, 2001, 2002, 2003, 2004, 2005, 2006, 2007, 2008, 2012, 2014, 2016, 2017) are normal 6 years $(1989,1993,1995,2000,2010,2018)$ are early and 4 years $(2009,2011,2013,2015)$ are late monsoon withdrawal years.
Withdrawal trend has been shown in Fig 4.4. The withdrawal dates also show sharp delayed trend in recent years, especially after 2005. This indicated that the state showed significantly delayed withdrawal trend for the period 1989-2018. The withdrawal dates show delayed trend of 0.25 days per year. Linear Regression tests on the date of withdrawal for 19892018 showed that the test statistic is higher than the critical value at $5 \%$ significance level indicating a very strong evidence of delayed trend (late withdrawal). The summary of the test results for the date of monsoon onset and withdrawal for 1989-2018 are given in the Table 2. 


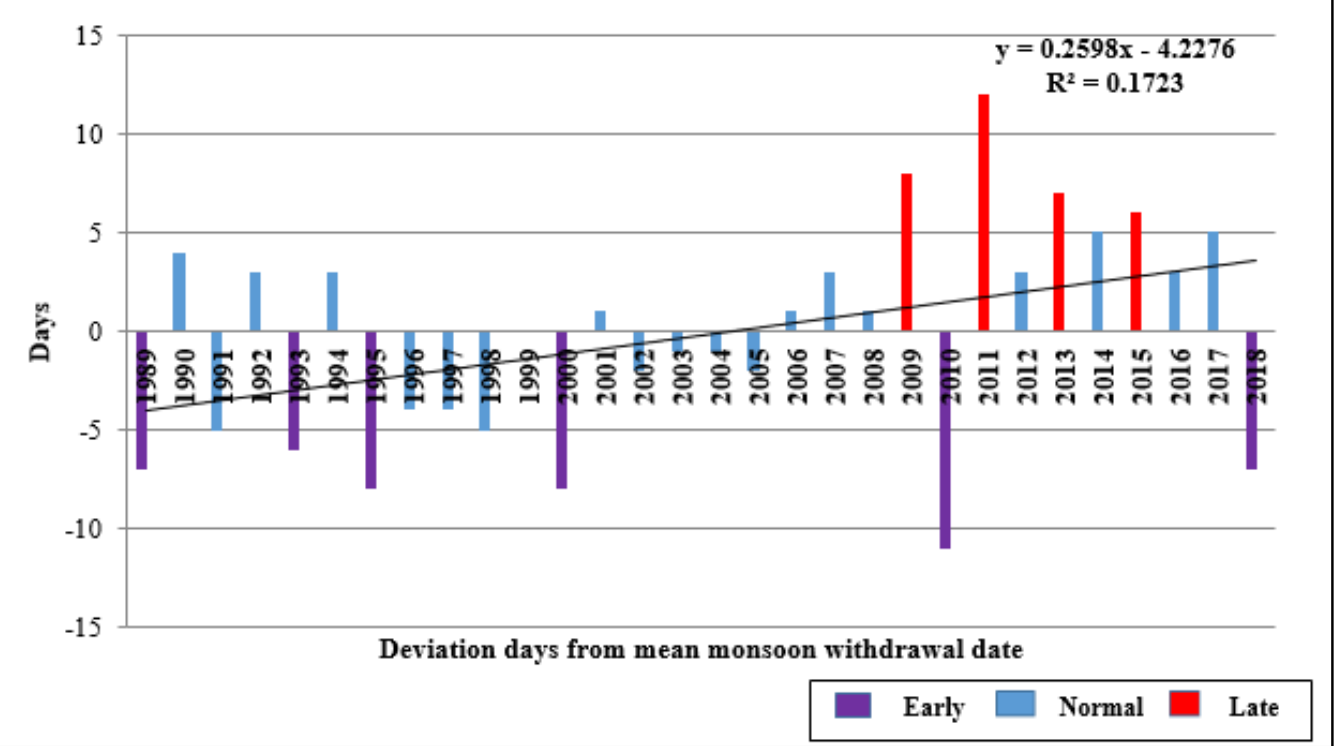

Fig 5: Trend of monsoon withdrawal from Chhattisgarh.

\section{Discussions and conclusions}

Review of 30 years of data revealed a large Inter-annual variability in the dates of the onset and withdrawal of SouthWest Monsoon over Chhattisgarh. Both the dates of southwest monsoon's onset and withdrawal are found to be delayed in recent years. There is a delayed trend over Chhattisgarh after 2004 for both the date of monsoon onset and the withdrawal. Of Chhattisgarh's three agro-climatic zones, only the Northern Hill Zone showed a significant delay in the trend of monsoon onset at a 5 percent significant level for the period 1989-2018. The highest coefficient value of variation of monsoon onset dates was reported in the Bastar Plateau zone and least in the Northern hill region. The withdrawal of monsoon results indicates that for the period 1989-2018 the state showed a significantly delayed withdrawal pattern at a significance level of 5 per cent. This result is consistent with Goswami et al. (2010) [5] finding for Indian summer monsoon's onset period, which has dramatically slowed down in the past decade compared to decades before. Goswami et al. (2010) ${ }^{[5]}$ proposed that the onset delay was due to the systemic weakening of the vertical east wind shear and the north-south gradient of the low-level mean humidity around the equator. Lacombe \& McCartney (2014) analyzed patterns in monthly and seasonal cumulative rainfall depth, number of rainy days, maximum daily rainfall and frequency of monsoons (onset, peak and retreat). Based on their study, they found that the pattern of monsoon onset in Northern India was delay at 5 per cent -field-significant. Xavier et al. (2007) ${ }^{[14]}$ studied the inter-annual variability of Summer Monsoon in India. Based on their diagnosis of the onset and withdrawal processes, their study indicates that the onset delay is due to the enhanced adiabatic subsidence that inhibits the vertical mix of sensitive heating from warm soil during the premonsoon months. On the other hand, the main factor determining whether the withdrawal is early or late is the horizontal advection cooling. Most of the late (early) onset and early (late) withdrawals are linked with El Niño (La Niño). This relation between the ENSO and the monsoon is realized through vertical and horizontal advections associated with stationary waves in the upper troposphere formed by the tropical ENSO heating. This increasing trend in the onset and withdrawal of the monsoon affects the region's crop pattern, crop growth, and yield, while decreasing monsoonal phenomenon that adversely affect water availability in Chhattisgarh's various locations. The considerable variability at the onset, withdrawal and duration of the summer monsoon exerts strong stress on the agriculture, water resources, hydropower generation, ecosystems, human health and the economy of the country as a whole. Further detailed investigation is needed to clearly attribute the temporal shift in the monsoon pattern over Chhattisgarh to the impact of global climate change and is therefore recommended for future studies.

\section{References}

1. Chand BK, Trivedi RK, Dubey SK, Beg MM. Aquaculture in changing climate of Sundarbans. Survey Report on Climate Change Vulnerabilities, Aquaculture Practices and Coping Measures in Sagar and Basanti Blocks of Indian Sundarbans, West Bengal University of Animal and Fishery Sciences, Kolkata, India. Online at http://www.wbuafscl.ac.in/, 2012.

2. Choudhury BU, Singh AK, Pradhan S. Estimation of crop coefficients of dry seeded irrigated rice-wheat rotation on raised beds by field water balance method in the IndoGangetic plains, India. Agric Water Manag. 2013; 123:20-31

3. Gadgil S, Gadgil S. The Indian monsoon, GDP and agriculture. Econ Polit wkly. 2006; 41(47):4887-4895

4. Goswami BN, Ajayamohan RS. Intraseasonal oscillations and interannual variability of the Indian summer monsoon J. Clim. 2001; 14:1180-98

5. Goswami BN, Kulkarni JR, Mujumdar VR, Chattopadhyay R. Short communication on factors responsible for recent secular trend in the onset phase of monsoon intraseasonal oscillations. Int. J Climatol. 2010; 30:2240-2246.

6. Ghosh S, Das D, Kao SC, Ganguly AR. Lack of uniform trends but increasing spatial variability in observed Indian rainfall extremes. Nature Clim Chang. doi:10.1038/Nclimate1327, 2012.

7. Jain SK, Kumar V. Trend analysis of rainfall and temperature data for India. Curr Sci. 2012; 102(1):37-49.

8. Mishra S. Climate change and adaptation strategy in Agriculture a West Bengal scenario. Geog Rev Ind. 2012; 74:1-16. 
9. Rosenzweig MR, Binswanger HP. Wealth, weather risk, and the composition and profitability of agricultural investments Policy research working papers vol. 1055Preworking papers vol. 1055 (Washington, DC: World Bank Publications), 1992.

10. Rupa K, Pant GB, Parthasarathy B, Sontakke NA. Spatial and sub-seasonal patterns of the long-term trends of Indian summer monsoon rainfall. Int. J Climatol., 1992; 12:257-268.

11. Sabeerali CT, Rao SA, Ajayamohan RS, Murtugudde R. On the relationship between Indian summer monsoon withdrawal and Indo-Pacific SST anomalies before and after 1976/1977 climate shift Clim. Dyn. 2012; 39:84159.

12. Singh SK, Singh KM, Singh RKP, Kumar A, Kumar U. Impact of Rainfall on Agricultural Production in Bihar: A Zone-Wise Analysis. Environment \& Ecology. 2014; 32(4A):1571-1576.

13. Singh D, Tsiang M, Rajaratnam B, Diffenbaugh NS. Observed changes in extreme wet and dry spells during the South Asian summer monsoon season Nat. Clim. Change. 2014; 4:456-61.

14. Xavier PK, Marzin C, Goswami BN. An objective definition of the Indian summer monsoon season and a new perspective on the ENSO-monsoon relationship. 2007; 133:749-764. 